\title{
Enhanced Cooperation, EMU Reforms and Their Implications for Differentiation in the European Union
}

\author{
Tomasz Kubin
}

\author{
Faculty of Social Sciences, \\ Institute of Political Sciences and Journalism, \\ University of Silesia in Katowice \\ ul. Bankowa 11, \\ Katowice 40-007, Poland \\ E-mail: tomasz.kubin@us.edu.pl
}

Abstract: Initially, before the entry into force of the Maastricht Treaty, differences in integration between members of the European Communities (EC; later the European Union) were relatively few and usually temporary in nature. The Schengen Agreement, the Maastricht Treaty and the Treaty of Amsterdam, and the possibility of establishing enhanced cooperation meant that the problem was becoming more and more important in the functioning of the EU-both in theory and in practice.

The objective of the paper is to show that for several years, along with the stagnation in the deepening of integration between all the EU Member States, differentiation of integration in the EU is progressing very rapidly. The progressing differentiation in the EU is a consequence of mainly two processes: the development of enhanced cooperation and reforms in the eurozone, which are strengthened by the widening of the $E U$.

The article covers the issue of the categorization of differentiation of European Union integration, which constitutes the theoretical framework for further considerations. Specified processes which contribute to increasing the differentiation of the EU are discussed, showing the development of enhanced cooperation in the EU and presenting the reforms of the eurozone. The article concludes with the identification and the consequences of differentiated integration, both those that have already occurred and those that may occur in the future.

Keywords: differentiated integration, enhanced cooperation 


\section{Introduction}

Since the launch of the Economic and Monetary Union (EMU) in 1999, the European Union (EU) failed to successfully introduce a project that would deepen integration and which would include all Member States without exception. The Treaty of Lisbon (TL) is only a reaction to the failure to ratify the Treaty establishing a Constitution for Europe.

The objective of the paper is to show that for several years, along with the stagnation in the deepening of integration between all the EU Member States, differentiation of integration in the EU is progressing very rapidly. For several decades of the integration process, the principle of unitary integration constituted its base and "meta-frame". Differentiated integration was seen in a negative light, as a phenomenon which was sometimes necessary, albeit exceptional and temporary, or "as directly damaging, even destructive of, solidarity" (Dyson \& Marcusen, 2010, p. 18). The progressing differentiation in the EU is a consequence of two key processes. The first is the practical application of the provisions on enhanced cooperation, which had remained dormant for about a decade. The second process involves the reforms in the eurozone introduced in the wake of the economic crisis, which meant the deepening of integration, albeit only between countries belonging to the monetary union. As a consequence, the differences in the depth of integration between the states belonging and not belonging to the eurozone are deepening further still. As a result, if we were to use an axis where one end signified unification, whilst the other differentiation, we would see that the EU is moving increasingly faster towards differentiation. This trend poses a challenge for the functioning of the EU and the integration process. So, the paper relates to the one of the geographical types of differentiation - differentiation within EU borders (Kölliker, 2006, p. 51).

This tendency is strengthened by what may be considered as EU's most effective instrument having an impact on security and stability—namely, the widening of the EU. So far, the subsequent stages of EU widening (previously, widening of the European Communities; EC) were accompanied by far-reaching measures aimed at deepening integration. Meanwhile, along with EU's largest ever enlargement in the years 2004-2013 when 13 new Member States were admitted into the EU, no project aimed at deepening EU integration has been effectively implemented. 
The paper deals with two aspects of differentiation in the EU-legal and institutional. Economic, political or identity-based differences, though very important for the EU, are not discussed here. The first part of the article is devoted to the issue of the categorization of differentiation of EU integration, which constitutes the theoretical framework for further considerations. The second part contains examples of differentiation of integration in the EU (EC) before 2010. The next two parts relate to specified processes, which contribute to increasing the differentiation of the EU- the third part shows the development of enhanced cooperation in the EU whilst the fourth part mentions the reforms of the eurozone. The fifth part is devoted to the identification and the consequences of differentiated integration, both those that have already occurred and those that may occur in the future. The main conclusions are contained in the summary.

\section{Categorization of the concept of differentiated integration in the European Union}

According to a frequently cited definition, the differentiation of integration in the EU is "the differential validity of formal EU rules across countries" (Schimmelfenning \& Winzen, 2014, p. 356) or "the possibility of Member States to have different rights and obligations with respect to certain common policy areas" (Kölliker, 2006, p. 14). Differentiation sensu lato means "instances where Member States (or regions within Member States) are not subjected to a uniform legal regime, even though they concern matters which fall within the scope of application" of the treaties. Differentiation sensu stricto concerns "instances where EU primary or secondary law distinguishes between its addressees". The use of the term 'differentiation' in both presented meanings is not mutually exclusive (Tuytschaever, 1999, pp. 2-3). A broader definition, in which two aspects of differentiation - functional and territorial — is brought together has been proposed by Kenneth Dyson and Angelos Sepos (2010, p. 4).

The concept of differentiated integration in the framework of the EC emerged in politics in 1974 in a speech of the chancellor of the Federal Republic of Germany Willy Brandt, and then in Leo Tindemans' report presented in 1976 (Piris, 2012, p. 67; Ehlermann, 1998, p. 249). The concept made way for a political and scientific debate, which has continued for several decades now. It resulted in interesting theoretical and empirical achievements, which, however, do not exhaust all the issues and are not fully structured (Holzinger 
$\&$ Schimmelfennig, 2012). The main theories of European integration, such as (liberal) intergovernmentalism, neofunctionalism or constructivism,

have not tried to explain the observed patterns of differentiation. Instead, research on the causes and consequences of differentiated integration has developed from general discussions about the alleged trade-off between deeper and broader participation in multi-lateral agreements (Zhelyazkova, 2014, pp. 728-729).

When attempting to organize the concepts relating to differentiated integration, Alexander C.-G. Stubb highlights the following factors as criteria of differentiation: time, space and matter. In the case of time-related differentiation, the individual states do not participate in integration projects simultaneously but at different times. The differentiation of integration, understood in the context of space, means that any one integration project is accepted only in a certain part of the territory of an organization. Finally, as regards the criterion of matter-individual integration projects are freely chosen by the members of the integration groupings as if from a restaurant menu (Stubb, 1996, pp. 283-285).

As noted by Katharina Holzinger and Frank Schimmelfennig (2012, pp. 296-297), the problem with Stubb's classification is that it is not analytically disjointed and they propose a classification based on six dimensions: (1) permanent $v$. temporary differentiation; (2) territorial $v$. purely functional differentiation; (3) differentiation across nation states $v$. multi-level differentiation; (4) differentiation that takes place within the EU treaties $v$. outside the EU treaties; (5) decision-making at the EU level $v$. at regime level; (6) only for Member States $v$. also for non-Member States/areas outside the EU territory. In another article, Frank Schimmelfennig and Thomas Winzen (2014, p. 355) introduce a distinction between the two types of differentiation in EU treaties, which differ in origin. The first is "instrumental differentiation", transitional and "motivated by efficiency and distributional concerns". It is a consequence of accepting states into the EU ("widening"). However, "constitutional differentiation" results from "treaty revisions among existing Member States, which transfer additional competences to the Union ('deepening')".

Filip Tuytschaever (1999, pp. 116-121) has also distinguished between several types of differentiation:

1) actual ("when primary or secondary law, upon its entry into force, establish a differentiated regime") and potential ("occurs when provisions of primary or secondary law do not by their very existence establish a differentiated regime, but form the basis for future actual differentiation"); 
2) inter-State differentiation (i.e. between EU Member States) and intra-State differentiation (i.e. between regions within Member States);

3) temporary and non-temporary;

4) general (concerning all Member States) and specific (concerning specifically designated Member States or regions);

5) positive (i.e. differentiation which occurs when "primary law permits a limited number of Member States to adopt rules which apply only as far as they are concerned") and negative (i.e. "differentiation which, actually or potentially, excludes one or several or all Member States, either temporarily or permanently, from a rule which is adopted by all Member States").

A division in which the aforementioned criteria of time, space and matter play a role is the distinction between "vertical" and "horizontal" differentiation. Vertical differentiation means that integration within a framework of common policies proceeds at different speeds and achieves various degrees of centralization. Horizontal differentiation means spatial differentiation and is based on the fact that arrangements concerning common policies do not apply in a uniform manner in all the Member States. Horizontal differentiation can be at the same time "internal differentiation" if not all EU Member States participate in a given political framework and "external differentiation", in which at least one country from outside the EU participates in a given political framework (Schimmelfennig, Leuffen \& Rittberger, 2015).

A simple division of states not only belonging to the EU is proposed by JeanClaude Piris, who distinguishes between a "two-speed" Europe and a "two-class" ("two-tier") Europe. In the first case, the diversity of integration is of temporary nature, i.e. states that at any given moment do not participate in a specified integration project join it later. However, the latter concerns the member states not all of which belong to the EU, and is something constant (Piris, 2012, pp. 6-7). Besides, according to Piris, it is more precise to speak of "multi-speed" integration rather than "two-speed" integration in relation to the EU, since the groups of states participating in the various integration projects are different. In the case of "multispeed" integration, all EU Member States do the same thing, but not at the same time or at the same pace. However, in the case of the "two-class" ("two-tier") Europe type, there is no fixed group of states participating in all projects, but in any case, other countries can be included into this group. This form of cooperation may lead to "multi-speed" integration (Piris, 2012, pp. 61-70).

A synthetic overview of the theoretical approaches, concepts and typologies relating to the differentiation of integration is included in the paper by Holzinger and Schimmelfenning (2012), whilst the concepts used with regard to 
differentiated integration and enhanced cooperation is discussed, for example, by Claus-Dieter Ehlermann (1998, pp. 246-247).

\section{Differentiation of integration in the $\mathrm{EU}(\mathrm{EC})$ before $\mathbf{2 0 1 0}$}

With the diversity of integration in the EU (EC) we have to start from the very beginning of the integration process. The most significant examples arising from the provisions of the EU (EC) primary law are:

- The right to establish "regional unions" between Belgium, Luxembourg and the Netherlands on the basis of Article 233, Treaty establishing the European Economic Community "in so far as the objectives of these regional unions are not achieved by application" of the EEC Treaty (present Art. 350 of the TFEU);

- Transition periods included in accession treaties, on the basis of which states joining the EC (EU) have time to fully customize their law to the acquis communautaire;

- The Schengen agreements (1985 and 1990) and the acquis developed later, which until 1999 remained outside the legal framework of the EU (European Union, 1997a);

- Economic and Monetary Union - according to former Article 109k of TEC (Treaty on European Union, 1992), the EU Member States that do not meet all the criteria for participation in the third stage of the EMU are covered by a derogation, what means that they remain outside the euro area (present Art. 139 of the TFEU);

- The right of the United Kingdom (European Union, 1992b) and Denmark (European Union, 1992a) not to participate in the third stage of the EMU;

- The right of Denmark to keep its legislation on the acquisition of property (European Union, 1992d);

- The right of the United Kingdom not to participate in "Agreement on social policy" concluded between the remaining eleven EC Member States (European Union, 1992c);

- The right of the United Kingdom and Ireland to exercise control on the borders of these states with other EU (EC) states regardless of the then Article $7 \mathrm{a}$ of TEC. On the basis of reciprocity, the same rights were granted to other EU (EC) Member States, to which people entered from the United Kingdom and Ireland (European Union, 1997b);

- The United Kingdom, Ireland (European Union, 1997d) and Denmark (European Union, 1997c) were not bound by the then Title IIIa of TEC 
(on visas, asylum, migration and other policies related to free movement of persons), unless these states would express willingness to participate in measures and actions adopted within the framework of these policies.

Another example of differentiation of integration was the Prüm Convention (Convention between 2006). It was signed on 27 of May 2005 by Austria, Belgium, France, Germany, Luxembourg, the Netherlands and Spain and concerned stepping up cross-border cooperation, particularly in combating terrorism, cross-border crime and illegal migration. In 2008, provisions of the Prüm convention have been incorporated in the EU acquis (Council Decision 2008/615/JHA, Council Decision 2008/616/JHA).

At last, according to the new protocol attached to the EU treaties on the basis of the Treaty of Lisbon, provisions contained in the title IV of the Charter of Fundamental Rights do not create "justiciable rights applicable to Poland or the United Kingdom except in so far as Poland or the United Kingdom has provided for such rights in its national law" (European Union, 2007a).

\section{Development of enhanced cooperation in the European Union}

Enhanced cooperation is one of the examples of the flexibility of the process of integration, and its introduction into EU's primary law was de jure a strengthening and confirmation of the departure from the general principle (this situation was de facto present from the inception of the EC), stating that in the framework of the integration process, all Member States shall adopt the same legal regulations at the same time. Enhanced cooperation, introduced into EU primary law by virtue of the Treaty of Amsterdam (1997; TA), apart from cooperation based on special arrangements (largely via "protocolization") and constructive abstention and opt-outs, was one of the three types of flexibility in the TA (Philippart \& Edwards, 1999, p. 98).

In accordance with the provisions of the Treaty of Lisbon (2007), arrangements for enhanced cooperation have been included both in the TEU, in Article 20 (Consolidated version of the Treaty on the European Union, 2012), and in the Consolidated version of the Treaty on the functioning of the European Union (TFEU; 2012). The detailed regulations, which clarify the content of Article 20 of the TEU, are contained in Articles 326-334 of the TFEU.

For about a decade since the introduction of the TA, the provisions concerning enhanced cooperation were not used in practice. Theoretical attempts to explain 
how and when enhanced cooperation is undertaken were made by, for example, Daniela A. Kroll and Dirk Leuffen (2015). For the first time, the EU Council decided that all the conditions required by the TEU and the TFEU for it to be established have been met, and adopted the relevant decision on 12 July 2010, authorizing enhanced cooperation in the area of the law applicable to divorce and legal separation between Belgium, Bulgaria, Germany, Spain, France, Italy, Latvia, Luxembourg, Hungary, Malta, Austria, Portugal, Romania and Slovenia (Council Decision 2010/405/EU). ${ }^{1}$ As a consequence, on 20 December 2010, these 14 states adopted the regulation (Council Regulation 1259/2010/EU), which became applicable on 21 June 2012. ${ }^{2}$

The establishment of enhanced cooperation for the second time concerned unitary patent protection (UPP) in the EU. The decision to undertake enhanced cooperation was taken in accordance with Article 329, Section 1 of the TFEU by the EU Council of 10 March, 2011 (Council Decision 2011/167/EU). On its basis, all EU states, with the exception of Italy and Spain, participated in enhanced cooperation on a uniform system of patent protection. The package making up the UPP consists of two regulations: one concerning unitary patent protection (Regulation 1257/2012/ EU), the related appropriate language regulations (Regulation 1260/2012/EU) and an international agreement that is expected to create a Single Patent Court before which disputes would be settled (Agreement..., 2013).

Actions aimed at the establishment of enhanced cooperation in the field of the UPP were met with opposition from Spain and Italy. They appealed the decision of the Council to the EU Court of Justice. In its judgment of 16 April 2013, the EU Court of Justice considered all the arguments of Spain and Italy as unjustified, and therefore dismissed the complaints of these Member States (Joint Cases C-274/11 and C-295/11). However, in March 2013, Spain launched two new challenges with the EU Court of Justice against the regulations implementing the unitary patent system. In its judgments (5 May 2015), the EU Court of Justice fully dismissed the Spanish claims (Case C-146/13 and Case C-147/13).

Following a request by the government of Italy, it became a participant of unitary patent regulations in September 2015 (Commission Decision 2015/1753/EU). As a result, all the EU Member States, except Spain and Croatia, take part in the enhanced cooperation in unitary patent protection system.

1 See more on this problem, e.g., Peers, 2010, pp. 339-358; Kuipers, 2012, pp. 201229; Fiorini, 2010, pp. 1143-1158.

2 On 21 November 2012, the Commission adopted the decision 2012/714/EU confirming the participation of Lithuania and on 27 January 2014 of Greece (Commission Decision 2014/39/EU) in enhanced cooperation in the area of the law applicable to divorce and legal separation. 
The third instance of establishing enhanced cooperation was with regard to financial transaction tax (FTT). The EU Council adopted a decision authorizing enhanced cooperation in the area of FTT on 22 January 2013 (Council Decision 13/52/EU). In accordance with Article 1 of this decision, it authorizes 11 Member States (Belgium, Germany, Estonia, Greece, Spain, France, Italy, Austria, Portugal, Slovenia and Slovakia ${ }^{3}$ ) to engage in enhanced cooperation for the purpose of establishing a common FTT system.

Just as in the case of the UPP, the decision of the EU Council authorizing the establishment of enhanced cooperation in the field of FTT was challenged in the EU Court of Justice. On April 18, 2013, the United Kingdom, on the basis of Article 263 of the TFEU, filed a complaint for the annulment of EU Council decision 13/52/EU in connection with violation of Articles 327 and 332 of the TFEU and the customary international law (Case C-209/13). In its judgement, the EU Court of Justice both refuted the pleas raised by the United Kingdom and dismissed this state's complaint (Item 40).

An overview of differentiated membership of the EU's Member States in the three enhanced cooperations is provided in Figure 1.

Figure 1. Membership of the EU's Member States in enhanced cooperation in the EU

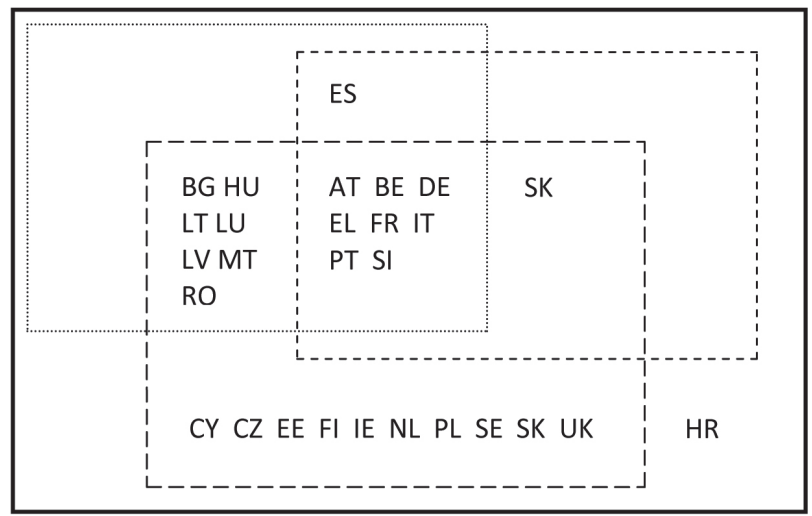

- - EU 28

……...... - EU participants of the enhanced cooperation in law applicable to divorce and legal separation

- - - - - EU participants of the enhanced cooperation in financial transactions tax

- - - - EU participants of the enhanced cooperation in unitary patent protection

Source: Own work inspired by Kölliker, 2006, p. 20.

3 In December 2015, Estonia announced that it no longer supports the financial transactions tax. This state is concerned that the tax would hardly generate any revenue, while scaring away financial institutions at the same time. 


\section{Reforms of the eurozone as a factor enhancing differentiated integration in the EU}

The fact that some EU Member States would remain outside the eurozone had already been taken into account when the legal bases for the Economic and Monetary Union (EMU) were created. In accordance with Article 109k of the TEEC (Treaty on European Union, 1992), the EU Member States that do not meet all of the criteria for participation in the third stage of the EMU are covered by a derogation. Currently, this is the subject of Article 139 of the TFEU. Furthermore, the United Kingdom and Denmark were given the opportunity not to participate in the third stage of the EMU on the basis of the relevant protocols (European Union, 1992a, b).

The economic crisis and the measures and decisions taken in connection with it by the Member States and EU institutions have become a factor that greatly contributed to enhancing differentiation within the EU. The main criterion for the strengthening of this differentiation is membership or remaining outside the eurozone. A formal expression of the deepening of the political and institutional differentiation between the EU countries belonging to the Monetary Union and other countries, is the new Protocol on the Euro Group (European Union, 2007b) attached to the TL.

For the purpose of strengthening control over the budgetary policies of EU States, preventing excessive budget deficits and intensifying and accelerating the imposition of penalties for failure to meet commitments, the so-called Six$\mathrm{Pack}^{4}$ measures were adopted in 2011 . Two of its legal acts only apply to those EU Member States whose currency is the euro (Regulations 1173/2011/EU and 1174/2011/EU).

Another very significant document consolidating and deepening divisions among the EU states is the Treaty on Stability, Coordination and Governance in the Economic and Monetary Union (2012), colloquially called the fiscal compact. An agreement as to its conclusion was agreed at the summit of the euro area countries on December 9, 2011 (Euro Summit Statement, 2011) and it was eventually signed at a meeting of the European Council on 2 March 2012 by representatives of all the EU states, except the United Kingdom and the Czech Republic. This Treaty applies to the countries of the euro area (Art. 1(2)), and

4 The "Six-Pack" consists of five regulations of the European Parliament and of the Council (1173/2011, 1174/2011, 1175/2011, 1176/2011, 1177/2011) and directive of the Council 2011/85/EU. 
to those countries which signed and ratified it, and have declared that they wish to be bound earlier by some or all of the provisions of Title III and IV of the Treaty (Art. 14(5)). ${ }^{5}$

Yet another document, the importance of which is not as significant once the said Six-Pack and fiscal compact are adopted, but which needs mentioning, is the Euro Plus Pact. It was adopted at the meeting of the European Council on 24 and 25 March 2011 by yet another configuration of EU states than was the case when the aforementioned documents were signed. This group consisted of Poland, Bulgaria, Denmark, Lithuania, Latvia and Romania, constituting yet another manifestation of the progressive differentiation in the EU (The Euro Plus Pact, 2011). The Euro Plus Pact is a form of cooperation formally outside the institutional framework of the EU, although, in accordance with its provisions, EU institutions are used for the delivery of its objectives.

At the same meeting of the European Council (24-25 March 2011), several decisions were also made which perpetuate the differences between the Member States of the euro area and the other members of the EU to an even greater degree. Namely, the European Council (2011) decided to add to Article 136 of the TFEU a paragraph, according to which members of the EMU can establish a "stability mechanism", under which it will be possible to grant financial assistance. In connection with this decision, the European Council decided that the states of the euro area would set up a permanent European Stability Mechanism (ESM). What is especially important in the context of differentiated integration in the $\mathrm{EU}$ is, first of all, that this mechanism is only supposed to serve the needs of the states of the euro area exclusively. The participation of states from outside the eurozone would only be limited to participation in providing assistance to euro area countries.

5 Among the members of the EU, several groups of countries formed with different statuses in relation to the "fiscal compact":

- Eurozone Member States, which are bound by all Treaty provisions (19 states);

- Denmark and Romania, which have declared themselves to be bound by all Treaty titles;

- Bulgaria, that declared itself bound by all Treaty titles except of Title IV;

- Sweden, Poland and Hungary, which are not bound by any of the fiscal or economic provisions, but to which applies only Title V, covering euro summit participation (automatically applies for ratifying non-eurozone member states);

- United Kingdom, Czech Republic and Croatia, which are not parties of the fiscal pact and which may accede to the Treaty. 


\section{The importance of differentiated integration for the functioning of the European Union}

In the process of European integration, we are dealing with a set of three closely related trends: deepening (new common policies and the progressive centralization in already existing common policies), widening (the adoption of new Member States) and, especially since the 1990s, differentiation. Between them there are close interconnections and interdependencies, but their nature is clearly changing.

Though the European Communities were, generally, "based on the principle of equal rights and obligations for all Member States with respect to all Community policies" (Kölliker, 2006, p. 2), a certain level of differentiated integration in the $\mathrm{EC}$ (and later in the EU) has been present since the beginning of the integration process. At the beginning of the EC, integration was territorially (horizontally) and functionally (vertically) limited with a high level of unification (Leuffen, Rittberger, \& Schimmelfenning, 2013, pp. 26-27). Having regard to the different types of integration differentiation indicated in the first part ("instrumental" and "constitutional"), introduced by Schimmelfenning and Winzen, and taking into account the period from 1958 and the diversification lasting at least one year, the authors found 194 differentiations, 82 of which were introduced by the reform treaty and 112 by accession (Schimmelfenning \& Winzen, 2014, p. 364). At the same time, before the entry into force of the TM, the scale of differentiation in the primary law was very low-only $1-2$ per cent of all treaty articles had an actual differentiation. With the entry into force of the Schengen agreements, this rose to above 30 per cent. The enlargement of the EU to include countries of Central and Eastern Europe, the TL, and the reforms in the EU meant an increase in the relevant provisions of the treaties which signified a differentiation in the EU to a level of around 43 per cent at the end of 2012 (Schimmelfenning \& Winzen, 2014, p. 358). Tuytschaever (1999, pp. 7-32) also writes on the differentiation in the TEEC, the SEA and the TM, while Winzen (2016) speaks of the differentiation in secondary law.

Up until the accession of 13 states from Central and Eastern Europe to the EU in the years 2004-2013, each extension was accompanied by measures aimed at farreaching integration. However, ever since the EU was enlarged by the countries of Central and Eastern Europe, a new situation evolved. This extension, the greatest in history, was not accompanied by an adequate, successful, deepening of integration. What is more, the provisions on enhanced cooperation contained in the TA, as was shown in the second part, opened the path to a greater differentiation 
in the EU. Given the categorization by Tuytschaever (1999), referred to in the first part, it should be pointed out that insofar as the changes in the treaties that led to differentiation in integration before the TA were of a "negative" nature, that is, they allowed certain countries of the EU (EC) not to participate in selected integrating projects, enhanced cooperation signified a differentiation of integration of a "positive" nature, that is, it provided those Member States that had the will and means with the possibility of participating in the cooperation. The difference lies in the fact that the potential differentiation of integration resulting from enhanced cooperation is, at least theoretically, unlimited. Eric Philippart and Geoffrey Edwards (1999, p. 105) wrote about the introduction of the provisions on enhanced cooperation stating "if it is not a revolution insofar as orthodoxy was always more a pious aspiration than a reality, it is a major modification of the ethos of the Community-method". In this way, widening became a factor conducive to differentiation; however, it increased not only because of enlargement (preferences and the possibilities of the new Member States), see, for example, Schimmelfennig's (2014) attempt to provide a theoretical explanation of the issue.

The threefold establishment of enhanced cooperation since the year 2010 means that enhanced cooperation is becoming an integral part of the functioning of the EU. The provisions on enhanced cooperation is of considerable importance for the functioning of the EU. Firstly, they provide the legal framework for the differentiation of integration which is already in progress. Secondly, the prospect of the enlargement of the EU by more than a dozen countries of Central and Eastern Europe triggered fears that their acceptance into the EU may, for example, impede the integration process as these countries will not want to, or will not be able to participate in all integration activities being undertaken (it is worth noting that the accession treaties from 2003, 2005 and 2011 were based on the "no opting-out" principle, that is only temporary derogations were accepted, but not definitive).

The more countries the EU integrates, the more likely it is to have a membership with heterogeneous preferences and capabilities. The more policy sectors it integrates, the more likely they will include value-laden or redistributive policies that provoke intense conflict and are difficult to manage and settle. Finally, the more supranationally centralized European integration becomes, the more it reduces state autonomy and the more likely it provokes nationalist backlash (Schimmelfenning \& Winzen, 2014, p. 360).

The provisions on enhanced cooperation were supposed to help circumvent any possible problems related thereto and ensure that the integration process 
would not lose its momentum. In theory, for an EU Member State, remaining outside an integration project means greater autonomy at the expense of a smaller say on the decisions being made. Empirical studies suggest that in some cases the difference between insiders and outsiders is vague and these countries have some influence on the content of the adopted legislation, as in the case of the United Kingdom and Denmark with regard to justice and home affairs (Adler-Nissen, 2009, pp. 64-65). The results of other studies (relating to the remaining of Britain, Denmark and Sweden outside of the eurozone) indicate that remaining outside, which results in, for example, "decreasing access to informal networks" in the decision-making process of the EU institutions, does not actually have to take place in practice (Naurin \& Lindahl, 2010). Therefore, according to Daniel Naurin and Rutger Lindahl (2010, pp. 505-506), "flexible integration may be a more realistic solution for dealing with intensified preference heterogeneity in the EU than previously anticipated". It should be noted that enlargement of the EU does not mean bigger differentiation in each case: some new Member States may have stronger tendency to foster the integration process than the old ones.

Thirdly, the following question should be posed: why should a group of EU countries that wish to deepen integration be restricted in their efforts to deeper integration by another state or several states unwilling to do so? And it would be difficult to justify why an EU state or a small group of states should be conferred the right to block other Member States in enhancing their mutual integration. Provisions on enhanced cooperation can be seen as an answer to this problem.

The impact of enhanced cooperation on the prevention of stagnation in the process of integration can be at least twofold. Firstly, the states which establish such cooperation may become a pioneering group that sets the trends, and after some time they are joined by more Member States encouraged by their example (Kölliker, 2006). Such a model is delivered especially in the framework of the EMU - the first 11 EU countries qualified for the third stage of Monetary Union in 1998 were joined later by other states. Secondly, the possibility that only a part of the Member States decide to deepen integration can act as a deterrent for the other EU Member States, which approach such a deepening from a distance or even with reluctance. Fear of marginalization, non-participation in the integration process fully, or bearing the mark of a secondary EU Member State may prompt these countries to join in the efforts to deepen integration as it might be better to participate in such a venture and attempt to influence the content of the amendments to suit its own interests from the inside than to stand on the sidelines and have no impact on the process whatsoever. The theoretical approach proposed by Kroll and Leuffen (2015, p. 367) acknowledges that the 
possibility of establishing enhanced cooperation is a factor which is conducive to the adoption of solutions by all EU Member States.

However, the undertaking of enhanced cooperation by a group of EU states may lead to a series of significant complications for the process of integration. Firstly, the abovementioned deterrence function of enhanced cooperation can also be looked at from another perspective. The point is that some Member States, which do not intend to take part in an integration project in the framework of the EU, may treat the risk of participating in enhanced cooperation by a group of EU states as a certain kind of "blackmail". As a result, participation in such an integration project may be perceived as something imposed, since the decision to participate in it will be made more for fear of remaining outside the mainstream of integration and being marginalized, rather than because of the perception that participation in the project is done in the interest of the country and due to a genuine desire to deepen integration. Secondly, if a group of EU states participates in all (or most) of these projects, this group will be seen as avant-garde, demonstrating a clearly deeper degree of integration compared with other Member States. In this situation, enhanced cooperation could become a factor leading rather to the disintegration within the EU and promoting the differentiation of EU states rather than a deepening of their integration. Jose M. de Areilza (2000, p. 73), for example, expressed the opinion that "in the end, it may come to be that the words 'Community' or 'Union' will invoke cynical smiles".

Another problem associated with enhanced cooperation is its compliance with the fundamental principles of integration in the EU and EU law, which include the principle of solidarity, equality of the Member States and the unity of EU legal standards. According to, for example, Slawomir Dudzik (2003), enhanced cooperation allows for the "replacement, at least in some cases, of the joint efforts of all Member States to achieve defined integration objectives by the actions of only some states". Enhanced cooperation "also introduces exemptions from the principle of equality of the Member States" with regard to EU law, because it leads to an "unjustified diversification of the rights and responsibilities of the Member States depending on whether they participate in circles of cooperation and how many such circles there are". In addition, the frequent use of enhanced cooperation will also "result in a progressive fragmentation of EU's legal system" and "a progressive erosion of the principle of unity of community order." (Dudzik, 2003, pp. 37-38) If enhanced cooperation was to be undertaken very often and by different groups of countries, this would inevitably lead to an increasingly greater diversification of legal standards in the Member States and to an erosion of the uniformity of the acquis communautaire of the EU. 
The development of enhanced cooperation and progressive differentiation is a challenge also for the functioning of EU institutions - that is, the participation in debates and the right to vote of the representatives of states not participating in a policy. For example, as noted by Jean-Claude Piris, theoretically, if less than half of the Member States (9-13) participate in enhanced cooperation and when the consent of the Commission is required, one can imagine a situation in which the members of the Commission coming from countries other than those which intend to establish enhanced cooperation, can block the adoption of a decision made by the Commission in this respect. The same applies to the European Parliament (Piris, 2012, pp. 118-119).

Another very interesting question is associated with the aforementioned issues. Karolina Rokicka (2005, p. 93) indicates the possibility of "establishing enhanced cooperation within the framework of already existing enhanced cooperations (the so-called multi-tier model) or the establishment of further enhanced cooperation in the same area in which one already functions (the socalled parallel model)" - and this is, after all, at least theoretically possible in a situation in which the establishment of enhanced cooperation only requires nine EU Member States. In EU law there are no regulations on this issue. In practice, of course, this would be certainly difficult and if it happened, it would signify very far-reaching complications for the EU law and even bigger problems for the functioning of EU institutions.

Decisions on enhanced cooperation have been contested at the EU Court of Justice by countries not participating in this cooperation. Such a state of affairs, in which two parties crystallize and a dispute between them arises, is rather difficult to be considered as something positively influencing the relations between the EU Member States. On the one hand, enhanced cooperation can become a cause of conflict in the EU. On the other hand, a factor that may relieve possible conflict is when groups of states participating in enhanced cooperation and those opposing it are different even if subsequent decisions on enhanced cooperation are made and challenged at the EU Court of Justice by the Member States not participating in this cooperation. This has been the case so far in the three presented situations. As is the case in many other aspects of the functioning of the EU, today's allies can become tomorrow's opponents, which will not prevent them from cooperating again the day after that.

Reforms of the eurozone very strongly contributed to an increase in differentiated integration in the EU. As a result, the difference between the states with a common currency and other members of the EU is even greater. In addition to this, the fiscal compact has the nature of an intergovernmental agreement 
adopted outside the legal framework of the EU (it is to be incorporated into EU law within five years), which has not been signed by all EU Member States. It appears that this may raise doubts whether EU institutions can act for the benefit of its signatories.

\section{Conclusion}

A deepening of differentiated integration in the EU (EC) accompanies each subsequent enlargement, though, as Schimmelfenning and Winzen (2014, p. 359) claim on the basis of their quantitative research, this is a temporary increase and the increase in differentiation "is neither linear nor irreversible". Differentiated integration in the EU can be perceived and justified as a "consensus-building strategy for countries with deviant preferences" (Winzen 2016, p. 102). However, it appears that the increase in differentiation observed in recent years requires us to look at it from a different perspective. This is because differentiation resulting from the development of enhanced cooperation and deepening of the integration of the euro area countries is much more significant for the cohesion of the EU than, for example, transitional periods when new countries accede to the EU (EC) or the exemptions contained in protocols appended to the treaties. The deepening of the integration of the euro area countries and the development of enhanced cooperation means not only a "quantitative" but above all, a "qualitative" increase in differentiation of integration in the EU. It seems that the biggest threat for the EU and the integration process may result not from the temporary differentiation of integration, but, above all, from the inability to join the more integrated group of the EU Member States by the ones which were not ready or willing to join from the beginning. In addition, taking into account the agreement developed by the European Council on 18-19 February 2016 (European Council, 2016), regardless of whether the UK will remain in the EU or leave the organization ${ }^{6}$, differentiation will increase. Should the decision be to remain in the EU, the worked out agreement will mean the entry into force of regulations which will continue to relax the ties connecting the UK to the EU. The consequences of UK's opting-out from the EU, apart from the extremely significant consequences for both the EU and the UK, also include, for example, a weakening the position of those states which currently, like the UK, do not participate in all the common policies of the EU. The main, albeit not new, issue related to the progressing differentiation is expressed by the following question:

6 The paper was completed before the 23 June 2016 referendum in the United Kingdom on remaining in or leaving the European Union. 
how much differentiated integration can the EU accommodate? The said factors require this question to be posed again and the issue of the so-called "integration trap" (Andersen \& Sitter, 2006) to be raised anew. In a broader context, it is worth mentioning that such factors as progressing globalization and increasing international competition, the global economic crisis and its implications or populist, radical and anti-EU political movements have a strong impact on the divisions among the EU Member States.

Tomasz Kubin, PhD and Dr. hab. in Social Sciences in the field of Political Science, is associate professor at the Department of International Relations, head of the Laboratory of European Integration at the Institute of Political Sciences and Journalism, University of Silesia in Katowice. He has also completed postgraduate courses in international trade (University of Economics in Katowice) and the law of European Union (Jagiellonian University). Kubin's main scientific interests are European integration (especially the institutional system of the European Union, Economic and Monetary Union, external relations of the EU, diversity of integration within the $\mathrm{EU}$ ), international relations and issues connected with Belarus.

\section{References}

Adler-Nissen, R. (2009), 'Behind the scenes of differentiated integration: Circumventing national opt-outs in justice and home affairs,' Journal of European Public Policy, vol. 16, no. 1, pp. 62-80. https://doi.org/10.1080/13501760802453239

Agreement... (2013), Agreement on a Unified Patent Court, Official Journal of the European Union, C 175/01, 20.06.2013.

Andersen, S. \& Sitter, N. (2006), 'Differentiated integration: What is it and how much can the EU accommodate?' Journal of European Integration, vol. 28, no. 4, pp. 313-30. https://doi.org/10.1080/07036330600853919

Commission Decision 2012/714/EU of 21 November 2012 confirming the participation of Lithuania in enhanced cooperation in the area of the law applicable to divorce and legal separation, Official Journal of the European Union, L 323/18, 22.11.2012. Commission Decision 2014/39/EU of 27 January 2014 confirming the participation of Greece in enhanced cooperation in the area of the law applicable to divorce and legal separation, Official Journal of the European Union, L 023/41, 28.01.2014.

Commission Decision 2015/1753/EU of 30 September 2015on confirming the participation of Italy in enhanced cooperation in the area of the creation of unitary patent protection, Official Journal of the European Union, L 256/19, 01.10.2015. 
Consolidated version of the Treaty on the European Union, Official Journal of the European Union, C 326/13, 26.10.2012.

Consolidated version of the Treaty on the Functioning of the European Union, Official Journal of the European Union, C 326/47, 26.10.2012.

Convention between... (2006), Convention between the Kingdom of Belgium, the Federal Republic of Germany, the Kingdom of Spain, the French Republic, the Grand Duchy of Luxembourg, the Kingdom of the Netherlands and the Republic of Austria on the stepping-up cross-border cooperation, particularly in combating terrorism, cross-border crime and illegal migration, Council of the European Union, 16382/06, Brussels, 06.12.2006. Retrieved from http://register.consilium.europa.eu/ doc/srv?l=EN\&f=ST\%2016382\%202006\%20INIT [accessed Aug 2017]

Council Decision 2008/615/JHA of 23 June 2008 on the stepping up of cross-border cooperation, particularly in combating terrorism and cross-border crime, Official Journal of the European Union, L 210, 06.08.2008.

Council Decision 2008/616/JHA of 23 June 2008 on the implementation of the Decision 2008/615/JHA on the stepping up of cross-border cooperation, particularly in combating terrorism and cross-border crime, Official Journal of the European Union, L 210, 06.08.2008.

Council Decision 2010/405/EU of 12 July 2010 authorising enhanced cooperation in the area of the law applicable to divorce and legal separation, Official Journal of the European Union, L 189/12, 22.07.2010.

Council Decision 2011/167/EU of 10 March 2011 authorising enhanced cooperation in the area of creation of unitary patent protection, Official Journal of the European Union, L 076/53, 22.03.2011.

Council Decision 2013/52/EU of 22 January 2013 authorising enhanced cooperation in the area of financial transaction tax, Official Journal of the European Union, L 022/11, 25.01.2013.

Council Regulation 1259/2010/EU of 20 December 2010 implementing enhanced cooperation in the area of the law applicable to divorce and legal separation, Official Journal of the European Union, L 343/10, 29.12.2010.

Council Regulation 1260/2012/EU of 17 December 2012 implementing enhanced cooperation in the area of the creation of unitary patent protection with regard to the applicable translation arrangements, Official Journal of the European Union, L 361/89, 31.12.2012.

de Areilza, J. M. (2000), 'Reforma instytucjonalna Unii Europejskiej a nowy ustrój europejski,' in E. Popławska (ed.) Konstytucja dla rozszerzającej się Europy, Warszawa: Wydawnictwo Instytut Spraw Publicznych, pp. 65-81.

Dudzik, S. (2003), 'Mechanizm wzmocnionej współpracy na tle konstytucyjnych zasad porządku prawnego Unii Europejskiej,' Kwartalnik Prawa Publicznego, no. 1, pp. 7-39. 
Dyson, K. \& Marcussen, M. (2010), 'Transverse integration in European economic governance: Between unitary and differentiated integration,' Journal of European Integration, vol. 32, no. 1, pp. 17-39. https://doi.org/10.1080/07036330903375107

Dyson, K. \& Sepos, A. (2010), 'Differentiation as design principle and as tool in the political management of European integration,' in K. Dyson \& A. Sepos (eds.) Which Europe? The Politics of Differentiated Integration, Basingstoke: Palgrave Macmillan, pp. 3-23. https://doi.org/10.1057/9780230289529_1

Ehlermann, C. D. (1998), 'Differentiation, flexibility, closer co-operation: The new provisions of the Amsterdam Treaty,' European Law Journal, vol. 4, no. 3, pp. 246-270. https://doi.org/10.1111/1468-0386.00052

European Council (2011), 24-25 March 2011 Meeting, Conclusions, EUCO 10/1/11, Annex 1. Brussels, 20 April 2011. Retrieved from http://www.consilium.europa. eu/uedocs/cms_Data/docs/pressdata/en/ec/120296.pdf [accessed Aug 2017] (2016), 18 and 19 February 2016 Meeting, Conclusions, EUCO1/16, Brussels, 19 February 2016. Retrieved from http://data.consilium.europa.eu/doc/document/ ST-1-2016-INIT/en/pdf [accessed Aug 2017]

European Union (1992a), Protocol on certain provisions relating to Denmark, Treaty on European Union, Official Journal of the European Communities, C 191/89, 29.07.1992.

(1992b), Protocol on certain provisions relating to the United Kingdom of Great Britain and Northern Ireland, Treaty on European Union, Official Journal of the European Communities, C 191/87, 29.07.1992.

_ (1992c), Protocol on social policy, Treaty on European Union, Official Journal of the European Communities, C 191/87, 29.07.1992.

— (1992d), Protocol on the acquisition of property in Denmark, Treaty on European Union, Official Journal of the European Communities, C 191/87, 29.07.1992.

_ (1997a), Protocol integrating the Schengen acquis into the framework of the European Union, Treaty of Amsterdam amending the Treaty on European Union, the Treaties establishing the European Communities and certain related acts, signed at Amsterdam, 2 October 1997, Official Journal of the European Communities, C 340/01, 10.11.1997. (1997b), Protocol on the application of certain aspects of Article 7a of the Treaty establishing the European Community to the United Kingdom and to Ireland, Treaty of Amsterdam amending the Treaty on European Union, the Treaties establishing the European Communities and certain related acts, signed at Amsterdam, 2 October 1997, Official Journal of the European Communities, C 340/01, 10.11.1997.

(1997c), Protocol on the position of Denmark, Treaty of Amsterdam amending the Treaty on European Union, the Treaties establishing the European Communities and certain related acts, signed at Amsterdam, 2 October 1997, Official Journal of the European Communities, C 340/01, 10.11.1997. 
(1997d), Protocol on the position of the United Kingdom and Ireland, Treaty of Amsterdam amending the Treaty on European Union, the Treaties establishing the European Communities and certain related acts, signed at Amsterdam, 2 October 1997, Official Journal of the European Communities, C 340/01, 10.11.1997.

(2007a), Protocol on the application of the Charter of Fundamental Rights of the European Union to Poland and to the United Kingdom, Treaty of Lisbon amending the Treaty on European Union and the Treaty establishing the European Community, signed at Lisbon, 13 December 2007, Official Journal of the European Union, C 306/153, 17.12.2007.

— (2007b), Protocol on the Euro Group. Treaty of Lisbon amending the Treaty on European Union and the Treaty establishing the European Community, signed at Lisbon, 13 December 2007, Official Journal of the European Union, C 306/153, 17.12.2007.

(2011), Statement by the Euro Area Heads of State or Government, Brussels, 9 December 2011. Retrieved from http://www.consilium.europa.eu/uedocs/cms data/docs/pressdata/en/ec/126658.pdf [accessed Aug 2017]

Euro Summit Statement (2011), Brussels, 26 October 2011. Retrieved from http://www. consilium.europa.eu/uedocs/cms_data/docs/pressdata/en/ec/125644.pdf [accessed Aug 2017]

Fiorini, A. (2010), 'Harmonizing the law applicable to divorce and legal separation - enhanced cooperation as a way forward?' International \& Comparative Law Quarterly, vol. 59, no. 4, pp. 1143-1158.

https://doi.org/10.1017/S0020589310000564

Holzinger, K. \& Schimmelfennig, F. (2012), 'Differentiated integration in the European Union: many concepts, sparse theory, few data,' Journal of European Public Policy, vol. 19, no. 2, pp. 292-305. https://doi.org/10.1080/13501763.2012.641747

Kingdom of Spain and Italian Republic v Council of the European Union [2013], C-247/11 and C-295/11, ECLI:EU:C:2013:240.

Kingdom of Spain $v$ Council of the European Union [2015], C-147/13, ECLI:EU:C:2015:299.

Kingdom of Spain v European Parliament and Council of the European Union [2015], C-146/13, ELI:EU:C:2015:298.

Kölliker, A. (2006), Flexibility and European Unification. The Logic of Differentiated Integration, Lanham: Rowman \& Littlefield Publishers, Inc.

Kroll, D. A. \& Leuffen, D. (2015), 'Enhanced cooperation in practice: an analysis of differentiated integration in EU secondary law,' Journal of European Public Policy, vol. 22, no. 3, pp. 353-373. https://doi.org/10.1080/13501763.2014.956781

Kuipers, J-J. (2012), 'The law applicable to divorce as test ground for enhanced cooperation,' European Law Journal, vol. 18, no. 2, pp. 201-229. https://doi.org/10.1111/j.1468-0386.2011.00594.x 
Leuffen, D.; Rittberger, B. \& Schimmelfenning, F. (2013), Differentiated Integration. Explaining Variation in the European Union, Basingstoke: Palgrave Macmillan. https://doi.org/10.1007/978-1-137-28501-0

Naurin, D. \& Lindahl, R. (2010), 'Out in the cold? Flexible integration and the political status of Euro opt-outs,' European Union Politics, vol. 11, no. 4, pp. 485-509. https://doi.org/10.1177/1465116510382463

Peers, S. (2010), 'Divorce, European style: the first authorization of enhanced cooperation,' European Constitutional Law Review, vol. 6, no. 3, pp. 339-358. https://doi.org/10.1017/S1574019610300022

Philippart, E. \& Edwards, G. (1999), 'The provisions on closer cooperation in the Treaty of Amsterdam: The politics of flexibility in the European Union,' Journal of Common Market Studies, vol. 37, no. 1, pp. 87-108. https://doi.org/10.1111/14685965.00151

Piris, J.-C. (2012), The Future of Europe: Towards a Two-Speed EU? Cambridge: Cambridge University Press.

Regulation 1257/2012/EU of the European Parliament and of the Council of 17 December 2012 implementing enhanced cooperation in the area of the creation of unitary patent protection, Official Journal of the European Union, L 361/01, 31.12.2012.

Rokicka, K. (2005), 'Wzmocniona współpraca w wymiarze sprawiedliwości i sprawach wewnętrznych UE,' in F. Jasiński \& K. Smoter (eds.) Obszar wolności, bezpieczeństwa i sprawiedliwości Unii Europejskiej. Geneza, stan i perspektywy rozwoju, Warszawa: Urząd Komitetu Integracji Europejskiej, pp. 81-103.

Schimmelfennig, F. (2014), 'EU enlargement and differentiated integration: Discrimination or equal treatment?' Journal of European Public Policy, vol. 21, no. 5, pp. 681-698. https://doi.org/10.1080/13501763.2014.897744

Schimmelfenning, F. \& Winzen, T. (2014), 'Instrumental and constitutional differentiation in the European Union,' Journal of Common Market Studies, vol. 52, no. 2, pp. 354-370. https://doi.org/10.1111/jcms.12103

Schimmelfennig, F.; Leuffen, D. \& Rittberger, B. (2015), 'The European Union as a system of differentiated integration: Interdependence, politicization and differentiation,' Journal of European Public Policy, vol. 22, no. 6, pp. 764-782. https://doi.org/10.1080/13501763.2015.1020835

Stubb, A. C.-G. (1996), 'A categorization of differentiated integration,' Journal of Common Market Studies, vol. 34, no. 2, pp. 283-295.

https://doi.org/10.1111/j.1468-5965.1996.tb00573.x

The Euro Plus Pact (2011), Stronger Economic Policy Coordination for Competitiveness and Convergence, European Council 24-25 March 2011, Conclusions, EUCO 10/1/11, Annex 1. Brussels, 20.04.2011.

Tuytschaever, F. (1999), Differentiation in European Law, Oxford: Hart. 
Treaty of Amsterdam amending the Treaty on European Union, the Treaties establishing the European Communities and certain related acts, signed at Amsterdam, 2 October 1997, Official Journal of the European Communities, C 340/01, 10.11.1997.

Treaty of Lisbon amending the Treaty on European Union and the Treaty establishing the European Community, signed at Lisbon, 13 December 2007, Official Journal of the European Union, C 306/01, 17.12.2007.

Treaty on European Union, Official Journal of the European Communities, C 191/01, 29.07.1992.

Treaty on Stability, Coordination and Governance in the Economic and Monetary Union. Brussels, 01.02.2012. Retrieved from http://europa.eu/rapid/press-release_DOC12-2_en.htm [accessed Aug 2017]

United Kingdom of Great Britain and Northern Ireland v Council of the European Union [2014], C-209/13, ECLI:EU:C:2014:283.

Winzen, T. (2016), 'From capacity to sovereignty: Legislative politics and differentiated integration in the European Union,' European Journal of Political Research, vol. 55, no. 1, pp. 100-119. https://doi.org/10.1111/1475-6765.12124

Zhelyazkova, A. (2014), 'From selective integration into selective implementation: The link between differentiated integration and conformity with EU laws,' European Journal of Political Research, vol. 53, no. 4, pp. 727-746.

https://doi.org/10.1111/1475-6765.12062 